\title{
Role of social media in academic achievement among Northern Border University sudents
}

\section{Papel de las redes sociales en el rendimiento académico de los estudiantes de la Northern Border University}

Received: February 18, 2021

\begin{abstract}
The study aimed to measure the impact of social media on academic achievement among a sample of Northern Border University students in the Kingdom of Saudi Arabia. The study seeks to reach a cognitive perception to recognize the effect of using social media on academic achievement in university students. It relied upon the quantitative and qualitative distribution of each type of social media application among students to determine the importance of social media informing study groups amongst themselves and with faculty members. This helped to identify the negative and positive effects of using social media applications on the process of academic achievement among Northern Border University students. To achieve those objectives, the researchers used the descriptive survey methodology, with the questionnaire used as a study tool. The most prominent results showed that a wide range of students at the University is highly interested in using social media in academic achievement and in communicating with the Faculty members. The study also concluded with a proposal to increase the activation of social media as an important tool for increasing the rate of academic achievement among Northern Border University students.
\end{abstract}

Abstract

Key Words: Social media, academic achievement, Northern Border University, social media and education, Technology Uses in Education.
Accepted: March 25, 2021

Written by:

Yaser Mohammad Al Sawy https://orcid.org/0000-0002-3150-9497

Feras Mohammed Al-Madani https://orcid.org/0000-0003-1739-5363

\section{Resumen}

El estudio tuvo como objetivo medir el impacto de las redes sociales en el rendimiento académico entre una muestra de estudiantes de la Northern Border University en el Reino de Arabia Saudita. El estudio busca llegar a una percepción cognitiva para reconocer el efecto del uso de las redes sociales en el rendimiento académico en estudiantes universitarios. Se basó en la distribución cuantitativa y cualitativa de cada tipo de aplicación de redes sociales entre los estudiantes para determinar la importancia de que las redes sociales informen a los grupos de estudio entre ellos y con los miembros de la facultad. Esto ayudó a identificar los efectos negativos y positivos del uso de aplicaciones de redes sociales en el proceso de rendimiento académico entre los estudiantes de Northern Border University. Para lograr esos objetivos, los investigadores utilizaron la metodología de encuesta descriptiva, utilizando el cuestionario como herramienta de estudio. Los resultados más destacados mostraron que una amplia gama de estudiantes de la Universidad está muy interesada en utilizar las redes sociales en el rendimiento académico y en la comunicación con los miembros de la facultad. El estudio también concluyó con una propuesta para incrementar la activación de las redes sociales como una herramienta importante para incrementar la tasa de rendimiento académico entre los estudiantes de la Northern Border University.

Palabras clave: Redes sociales, logros académicos, Northern Border University, redes sociales y educación, Usos de la tecnología en la educación.

\footnotetext{
${ }^{3}$ Associate Professor of Library and Information Science - College of Education and Arts - General Curriculum Dept.- Northern Border University - Saudi Arabia.

${ }^{4}$ Associate Professor of Education - Faculty of Education and Arts- Northern Border University - Saudi Arabia.
} 


\section{Introduction}

Social media is considered one of the forms of communication through the internet, used by people around the world. On the personal level, social media allows communication with family and friends (Yildiz et al, 2019) learning new things, works on developing personal interests, in addition to being means of entertainment. While on the professional level (Sapkota \& Vander, 2018), they can be used to expand knowledge in a specific field and build a professional network through communicating with other professionals in the field of work. At the company level, they allow communication between clients and the public and the promotion of the trademark (Razmjooei et al, 2019). While on the educational level, many educators find that social media networks, which are considered secondgeneration web tools, have made several changes, whether positive or negative (Naseem et al, 2019), in all fields of life. Moreover, their uses are no longer limited to communication and contacting individuals, instead, they have greatly surpassed that when they have come to be used in educational establishments and universities as an effective educational method and a communication mechanism between those active in the educational process (educator and educated), which bestowed on the process an interactive and dynamic character that was not available through classic education.

The results of previous studies looking into the educational role of social media varied. Some studies revealed the positive and important role of social media, as in the study by (Kalpidou et al, 2011), which showed Facebook as a social network that strengthens social relations and assists the social and psychological adaptation of students. The study by (Lee \& Lee, 2011) revealed that the use of social media networks has predictive indicators of the psychological and social adaptation of students. The results of (Zoabi, 2012) study showed high levels of selfesteem in students using Facebook.

Some studies revealed the negative role of social media as in the study by (Rouis et al, 2011), which indicated that Facebook does not place an important role in the academic performance of students. The results of (Lei \& Wu, 2007) study, also revealed a positive correlation between psychological isolation and the high number of hours using the internet.

The widespread of the various types of social media networks and the increased number of their users around the world, at 2.307 billion users according to this year (2016) statistics, with a $31 \%$ increase from the previous year, made those specialized in the educational field reconsider the educational methods to cope with the scientific and technological advances in the information community, after the traditional educational methods no longer cope with this community, which considers computers, the internet, and social media as its main and effective tools (West, 2017). On the other hand, think of means to use the features characterizing social media networks, such as seamless and free use, breaking the barriers of time and place, in addition to the interactive feature, without mentioning the services they provide to the benefit of the educational process. Based on that, they now use social media platforms in developing the educational process (Sidorov, 2019) the matter that made education specialists consider education through them as one of the most important distant education types (Alhamadi, 2017) due to the obvious effect they had on the efficiency of the educational process. Those media contributed to rebuilding a new formula for the relationship between the professor and the students on the one hand and amongst the students and the professors themselves, which will be a strong motive for learning to strengthen the relationship between those parties. This effect reached an extent that led some researchers to consider that social media platforms will soon completely substitute the traditional electronic education programs (Allam \& Elyas, 2016).

Despite the presence of several theoretical and field studies that affirmed the importance of social media in academic achievement at universities, and despite Northern Border University seeking to adopt social media as one of the enablers of academic achievement criteria, yet, there are no studies available in this field and on Northern Border University. This led the researchers to consider conducting a study to assess the use of social media in the academic achievement process at Northern Border University specifically, in addition to assessing the University's efforts to provide social media applications and how this reflects on the institutional performance at the University.

Accordingly, it is possible to summarize the study problem in the following questions:

1. What are the social media applications used by Northern Border University students in the academic achievement process? 
2. How to determine the extent and trends of use of each social media application?

3. What are the social media applications provided by Northern Border University to its students?

4. To what extent have social media applications contributed to improving the educational process for the students?

5. What are the obstacles that prevent the spread of social media applications among Northern Border University students?

6. What is the proposed concept for developing the technological capabilities of Northern Border University students for using social media applications to increase the academic achievement process?

The study aims to achieve the following:

1. Determining the actual use by the students of social media applications as one of the academic achievement enablers at Northern Border University.

2. Scientific analysis of the social media application used among the student body at the university.

3. Assessing the points of strength and weakness in using social media applications among Northern Border University students.

4. Defining the failures and obstacles limiting the students' ability to use social media in the academic achievement process.

5. Identifying the true availability by Northern Border University of social media applications to students.

6. Reaching specific outcomes for the study problem through which it is possible to prepare a specific proposal and recommendations for developing the technological capabilities of the student to use social media application to increase academic achievement.

The present study coincides with the interests and requirements for achieving the Kingdom of Saudi Arabia Vision 2030, which seeks to embed technology in every part of the Kingdom, with a special emphasis on education. Therefore, the study conforms to the requirements of the Vision. The study also addresses the variable of social media at universities (Northern Border University being an example), which seeks to implement quality and academic reliance standards, with social media being considered as one of the enablers to increase the academic achievement of students. Also, the study seeks to identify the present reality of the students' use of social media applications among the students of Northern Border University. Over and above that, the study sets a proposed concept and specific recommendations that can be relied on to activate the role of social media platforms at Northern Border University, to help improve student performance about increasing academic achievement.

\section{Study Theoretical Framework}

\section{Social Media}

A collection of technologies available over the web (Le, Dobele, \& Robinson, 2019) is used by people for communication and interaction purposes. This concept has recently developed to cause a serious riot. This concept means all electronic communication media available in the twenty-first century. Some individuals use the concept of social media applications loosely to describe the various types of cultural phenomena that include communication and not only communications technologies (Neto et al, 2015). In many cases, people use the expression social media to refer to the content provided by users through writing, publishing, or sharing using electronic publishing means. It is worth noting that the majority of social media forms are electronic, granting the users the ability to communicate and interact with each other using computers, smartphones, internet networks, and other social networks such as Facebook, Twitter, and Pinterest (Hassell \& Sukalich, 2016).

There is a large number of social media, the most important and popular of which are:

- Blogs: It is a platform for casual dialogue and discussions about a specific topic or a specific opinion.

- Facebook: It is considered the biggest social network in the world, used by more than 1.55 billion active users monthly according to 2015 statistics, where users open a personal profile, to which they add friends, exchange messages, and establish commercial pages.

- Twitter: A blog allowing groups and individuals to maintain contact through the exchange of short messages of up to 140 letters maximum.

- YouTube and Vimeo: Applications to watch videos and web applications.

- Flickr: An electronic site that allows the publishing of photos and video online, sharing photos on Facebook and Twitter, and other social media networks.

- Instagram: A free application that allows users to share photos and videos, use digital filters, frames, and special effects on photos, 


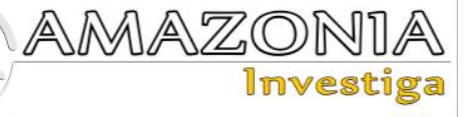

and then share them on varied social media applications.

- Snapchat: A mobile phone application that allows users to send images and video clips to their friends or to their story, which disappear after 24 hours of publication.

- LinkedIn: A site that allows groups of professionals with common fields and interests to share information and discussions.

\section{Forms of Social Media}

Social media vary; they also include social networks such as Twitter and LinkedIn. There are electronic means online to organize and manage communication between people individually or in groups (Sharma, 2019).

Social networks usually allow their visitors to form groups, allowing them to communicate. Another form of communication is also blogs, which provide a micro-blogging service. Some forms enable sharing videos, such as YouTube, and some are to exchange photos such as Instagram and Flickr (Santoveña-Casal, 2019) not to mention the services provided by some applications such as distant meetings, shopping, and distant buying and selling. Speaking about the limit for the spread of this media in communications (Sanderson, 2018), there are no indicators to show that this will happen soon, on the contrary (Shields \& Peruta, 2019) it is noticed that these media are adopting wider dimensions and are spreading more. Several inventions and ideas can arise from these media and despite the presence of some negative aspects for them, yet, we have to admit that they have some positive effect on the lives of many, as they facilitate communication despite the increased distances and travel (Dudin et al, 2019).

The rate of global events accelerated in the twentieth century, knowledge and science doubled in an unmatched way. This went handin-hand with the development of many various technologies that worked on facilitating life and filling the gaps resulting from the problems that prevailed around the world from east to west. Perhaps the field of education is one of the most prominent of the fields that modern technology had served and developed (Ahmed \& Hassan, 2017). The accelerated events created the need for solutions for the educational process, ones that would be able to cope with the significant scientific developments and the daily growing population needs (Alghamdi \& Hamed, 2019). This led communication technologies and media to play an effective role in this sensitive field. In the following, we shed light on the most prominent aspects related to such technologies and their relation to education.

\section{The Importance of Communication Means in Education}

Communication means play an important role in education, for there is an increased demand by students on learning, by making them partners in the use of these important means and technologies (Watson, 2017), and interacting with them. This all serves the interest of the student, as it works on establishing the academic subjects in his mind, in addition to allowing him to gain important and real scientific, practical, and life experiences (Freberg \& Kim, 2018). The use of communication means helps to develop the sense of beauty in students, through the ability to utilize these media to teach the art effectively and beautifully. Introduce the elements of entertainment and fun into the educational process, and avoid rigidity, dullness, and boredom, which could have a negative unfavorable effect on the students themselves. Develop the various abilities and senses of the students as such media uses all human senses effectively and significantly (Alruwaili \& $\mathrm{Ku}$, 2019). These media make the student the most important element in the educational process, in addition to contributing to changing the role of the educator, whose role is no longer limited to passing information to the students; instead, it exceeded that to other, more important roles (Melchiorre \& Johnson, 2017). The utilization of the various capacities of such media provides the opportunity for the students' feedback. It also contributes to lowering the cost of the educational process, while increasing quality in many cases.

\section{The Educational Roles of Social Media}

Social media is considered one of the interactive contributors to the development of education and turning the school from an educational environment limited by its walls to overcome the boundaries for education to transcend time and place (Kumar \& Nanda, 2019). Added to that, it includes all parties of the educational process with the community (Woods et al, 2019). including parents and various establishments, as well as bestows the social aspect of the educational process. Social media also increases communication opportunities, students' level of communication and dialogue skills. Furthermore (Aksoy, 2018). it works on raising the levels of social growth among students, through the student's participation in all social sectors of his 
virtual community within social media (Lundgren \& Crippen, 2019). It helps to eliminate the problems of shyness and introversion, through a real opportunity for virtual communication and the development of the student's social skills. (Hosseini et al, 2019) Therefore, Social media have become some of the important educational and social electronic establishments that play an important educational role in teaching the students and give them the proper educational knowledge, customs, and traditions if well managed (O'Neill, 2019).

\section{Research Methodology}

Represented in assessing the use by students of social media platforms to increase academic achievement. A stratified random sample of students from all specialties was selected during the academic year 2018_2019.

The study relied on the descriptive survey method, which allowed the collection of accurate data on the study subject focus of the research. The researchers used the (questionnaire) measurement tool, through which he was able to measure and analyze the opinions of a stratified random sample of students, to assess the effect of using social media platforms on increasing academic achievement.

The researchers also processed the data statistically using the statistical packages of the SPSS Statistics Program in its twenty-first edition, applying one of the non-parametric statistical methods (non-hypothesis), known as (Chi-squared) or (X2), where this test is necessary to process repetitions to determine their statistical significance, with (X2) used to calculate the significance in numerical data differences that can be converted into repetitions and measure the difference in observed frequencies and expected repetitions.

Therefore, the repetitions of sample responses to each of the objective items in the questionnaire shall be calculated. He set the statistical function of (X2) at (0.05), to represent good estimates, while the researchers saw items under $(0.05)$ as indicative of a deficiency in the relation.

The study also used two methods to verify the validity of the tool as follows:

1. Virtual validity: Through presenting the questionnaire to a group of specialists for assessment, grading, and amendment.

2. The validity of Internal Consistency: Pearson Correlation Coefficient was calculated to determine the internal validity of performance, whereas if the value of the correlation coefficient was under $(0.25)$ it would be considered low, between $(0.25$ $0.49)$ it would be considered moderate, while if its value was between $(0.50-0.75)$ the coefficient would be considered high and the relationship is strong. While if higher than that, it would mean that the relationship is very strong. The study also used Cronbach's Alpha equation to measure the stability of the study tool.

3. Each response was given a choice and weight based on a Likert three-point scale.

\section{Study Community and Sample}

Based on the aforementioned limits of the study, its community included a stratified random sample of university students, equal to (420) students as follows:

Table No. (1).

Shows the distribution of the individuals of the study sample by gender.

\begin{tabular}{lll}
\hline Gender & Frequencies & Percentage \% \\
\hline Males & 240 & 57 \\
Females & 180 & 43 \\
Total & 420 & 100 \\
\hline
\end{tabular}

Table No. (2).

Shows the distribution of the individuals of the study sample by academic specializations.

\begin{tabular}{llllll}
\hline $\begin{array}{l}\text { Academic } \\
\text { Specialization }\end{array}$ & Science & Engineering & $\begin{array}{l}\text { Medicine - } \\
\text { Pharmacy }\end{array}$ & Humanities & Total \\
\hline Frequencies & 130 & 20 & 70 & 200 & 420 \\
Percentage $\%$ & 31 & 4,7 & 6,6 & 46,7 & 100 \\
\hline
\end{tabular}




\section{ANAZOND周 \\ 1กveรtกำ}

1. Study Tool

A questionnaire was designed consisting of three main parts, the first deals with the characteristics of the sample members, the second deals with the actual use by the students of social media in academic achievement, while the third part deals with the role of the University in providing and facilitating the use of social media for its students.

\section{Tool Validity}

The researchers used two methods to verify the validity of the tool:

- Virtual validity:

After designing the questionnaire, the researchers presented it to a group of educational professionals. It included the following: The association between the questionnaire's statements and the study's objectives and questions, the quality of each statement's wording, and gradient in the questionnaire. Their comments and corrections were received. The researchers carried them out fully in terms of modifying the wording, deleting certain statements, adding certain explanatory statements, deleting and replacing words from the statement with other words for illustration.
The professionals nearly agreed on the quality and thoroughness of the arbiters compared to the study objectives and questions. Only one arbiter objected to the final formula, but it was approved by the other four.

- The validity of Internal Consistency

After ensuring the virtual validity of the study tool, the researchers distributed and applied the questionnaire in the field through personal interviews and distribution via e-mail to a stratified random sample of university students to a total of (500) questionnaires. After collecting the questionnaires, (80) of them representing $16 \%$ of the distributed questionnaires were invalid. SPSS was used in calculating the Pearson correlation coefficient to figure out the validity of the internal performance, as the correlation coefficient between the degree of each statement of the questionnaire and the total degree of the related part was calculated. The following table shows the Pearson correlation coefficient for each statement of the second and third parts of the questionnaire, noting that if the correlation coefficient value is less than $(0.25)$, it is low, if the value is $(0.25-0.49)$, it is considered medium and if the value is $(0.50-$ $0.75)$, it is considered high and strong. If the value is higher than the foregoing, it is considered very strong.

Table No. (3).

Showing the validity of the correlation of the questionnaire statements.

\begin{tabular}{lll}
\hline$\#$ & Statement & $\begin{array}{l}\text { Pearson correlation } \\
(P C C) \text { coefficient }\end{array}$ \\
\hline 1 & $\begin{array}{l}\text { Using social media applications in the educational process at } \\
\text { University } \\
\text { Types of social media applications used in academic achievement } \\
\text { Sufficiency of the social media used to fulfill the communication } \\
\text { needs with Colleagues and members of the faculty members } \\
\text { The extend of social media applications use in the educational } \\
\text { Process }\end{array}$ & $* * 0.432$ \\
4 & $\begin{array}{l}\text { Contribution of social media to achieving higher academic } \\
\text { Achievement }\end{array}$ & $* * 0.546$ \\
5 & $\begin{array}{l}\text { Obstacles facing the use of social media in the academic } \\
\text { achievement process }\end{array}$ & $* * 0.696$ \\
6 & $\begin{array}{l}\text { Northern Border University vision for the awareness of the use of } \\
\text { social media in the educational process } \\
\text { The University endeavors to dissemination and spread the } \\
\text { use of social media in the educational process }\end{array}$ & $* * 0.652$ \\
\hline
\end{tabular}

The previous table shows that all questionnaire question statements have a positive correlation, ranging between moderate to high, but not reaching the level of very high. This indicates that all the statements are valid in what they measure, represent the part to which they belong, and realize the internal validity element of the questionnaire.
3. Tool Reliability:

The researchers measured the reliability of the study tool (questionnaire) using Cronbach's Alpha (a) to ensure the reliability of the study tool. 
Table No. (4).

Shows the reliability coefficient of the study tool.

\begin{tabular}{ll}
\hline Axis & Reliability coefficient \\
\hline First axis: Actual use by students of social media in academic achievement & $* * 0.723$ \\
Second axis: Role of University in providing social media applications to its & $* * 0.545$ \\
students. & \\
\hline
\end{tabular}

The above Table shows that the values of the reliability coefficient of the questionnaire parts are high, indicating that the study tool (questionnaire) has a high degree of consistency and can be relied upon in the field application of the study.

\section{Statistical Processing}

The researchers used SPSS Program, using the following statistical methods:

1. Pearson correlation coefficient to calculate the accuracy of the questionnaire.

2. Cronbach's alpha coefficient to calculate the reliability of the questionnaire.

3. Frequency tables to calculate the percentage of each statement and to determine the degree of approval of each statement.

4. Chi-Square test to calculate the moral differences between the answers and the impact factor of the variable on the answer.

The study relied on the descriptive survey method, which allowed the collection of accurate data on the study subject focus of the research. The researchers used the (questionnaire) measurement tool, through which he was able to measure and analyze the opinions of a stratified random sample of students, to assess the effect of using social media platforms on increasing academic achievement.

The researchers also processed the data statistically using the statistical packages of the SPSS Statistics Program in its twenty-first edition, applying one of the non-parametric statistical methods (non-hypothesis), known as (Chi-squared) or (X2), where this test is necessary to process repetitions to determine their statistical significance, with (X2) used to calculate the significance in numerical data differences that can be converted into repetitions and measure the difference in observed frequencies and expected repetitions. Therefore, the repetitions of sample responses to each of the objective items in the questionnaire shall be calculated. He set the statistical function of (X2) at $(0.05)$, to represent good estimates, while the researchers saw items under (0.05) as indicative of a deficiency in the relation.

The study also used two methods to verify the validity of the tool as follows:

1. Virtual validity: Through presenting the questionnaire to a group of specialists for assessment, grading, and amendment.

2. The validity of Internal Consistency: Pearson Correlation Coefficient was calculated to determine the internal validity of performance, whereas if the value of the correlation coefficient was under $(0.25)$ it would be considered low, between $(0.25$ 0.49 ) it would be considered moderate, while if its value was between $(0.50-0.75)$ the coefficient would be considered high and the relationship is strong. While if higher than that, it would mean that the relationship is very strong. The study also used Cronbach's Alpha equation to measure the stability of the study tool.

3. Each response was given a choice and weight based on a Likert three-point scale.

\section{Discussion and Results}

The study reached many results that will be reviewed and discussed according to the use of social media for university students in academic achievement, as well as the most important forms of social media in academic achievement, in addition to the university's keenness to adopt the permanent and continuous use of these means in the educational process and the extent of communication between students in using All means of communication as following: 
1. Using social media in the educational process at university.

\begin{tabular}{llllll}
\hline Yes & $\begin{array}{l}\text { To some } \\
\text { extent }\end{array}$ & No & $\begin{array}{l}\text { X2 test on the gender } \\
\text { element }\end{array}$ & $\begin{array}{l}\text { X2 test on the } \\
\text { specialization element }\end{array}$ \\
\hline$\#$ & 198 & 141 & 81 & $\begin{array}{l}\text { P Value }=0.039 \\
\text { Differences in percentages are } \\
\text { significant, meaning that the } \\
\text { gender element affects the use of } \\
\text { social media in the educational } \\
\text { process }\end{array}$ & $\begin{array}{l}\text { P Value }=0.063 \\
\text { Differences in percentages are not } \\
\text { significant }\end{array}$ \\
$\begin{array}{l}\text { Meaning that the gender element } \\
\text { does not affect the use of social } \\
\text { media in the educational process }\end{array}$ \\
\hline
\end{tabular}

2. The most important types of social media applications used in academic achievement.

\begin{tabular}{|c|c|c|c|c|c|}
\hline \# & Social Media & $\begin{array}{l}\text { Size } \\
\text { of } \\
\text { usage }\end{array}$ & Percentage & $\mathrm{X} 2$ test on the gender element & $\begin{array}{l}\text { X2 test on the specialization } \\
\text { element }\end{array}$ \\
\hline 1 & Twitter & 331 & $78.8 \%$ & $\begin{array}{l}\mathrm{P} \text { Value }=0.061 \text {, meaning that the } \\
\text { gender element does not affect } \\
\text { the students' use of Twitter }\end{array}$ & $\begin{array}{l}\text { P Value }=0.027, \text { meaning that } \\
\text { the specialization element } \\
\text { affects the students' use of } \\
\text { Twitter }\end{array}$ \\
\hline 2 & Facebook & 387 & $92.1 \%$ & $\begin{array}{l}\mathrm{P} \text { Value }=0.041 \text {, meaning that the } \\
\text { gender element affects the } \\
\text { students' use of Facebook }\end{array}$ & $\begin{array}{l}\mathrm{P} \text { Value }=0.022, \text { meaning that } \\
\text { the specialization element } \\
\text { affects the students' use of } \\
\text { Facebook }\end{array}$ \\
\hline 3 & Instagram & 297 & $70.7 \%$ & $\begin{array}{l}\mathrm{P} \text { Value }=0.053 \text {, meaning that the } \\
\text { gender element does not affect } \\
\text { the Students' use of Instagram }\end{array}$ & $\begin{array}{l}\text { P Value }=0.047, \text { meaning that } \\
\text { the specialization element } \\
\text { affects the Students' use of } \\
\text { Instagram }\end{array}$ \\
\hline 4 & YouTube & 367 & $87.3 \%$ & $\begin{array}{l}\text { P Value }=0.037 \text {, meaning that the } \\
\text { gender element has } \\
\text { an effect on the students' use of } \\
\text { YouTube }\end{array}$ & $\begin{array}{l}\text { P Value }=0.067, \text { meaning that } \\
\text { the specialization element } \\
\text { does not affect the students' } \\
\text { use of YouTube }\end{array}$ \\
\hline 5 & Viber & 154 & $36.6 \%$ & $\begin{array}{l}\mathrm{P} \text { Value }=0.033 \text {, meaning that the } \\
\text { gender element affects the } \\
\text { students' use of Viber }\end{array}$ & $\begin{array}{l}\text { P Value }=0.038 \text {, meaning that } \\
\text { the specialization element } \\
\text { affects the students' use of } \\
\text { Viber }\end{array}$ \\
\hline 6 & My Space & 112 & $26.6 \%$ & $\begin{array}{l}\text { P Value }=0.074, \text { meaning that the } \\
\text { gender element does not affect } \\
\text { the students' use of My Space }\end{array}$ & $\begin{array}{l}\text { P Value }=0.025 \text {, meaning that } \\
\text { the specialization element } \\
\text { affects the students' use of My } \\
\text { Space }\end{array}$ \\
\hline 7 & Other & 167 & $39.7 \%$ & $\begin{array}{l}\text { P Value }=0.023 \text {, meaning that the } \\
\text { gender element has } \\
\text { an effect on the students' use of } \\
\text { other media }\end{array}$ & $\begin{array}{l}\mathrm{P} \text { Value }=0.034 \text {, meaning that } \\
\text { the specialization element } \\
\text { affects the students' use of } \\
\text { other media }\end{array}$ \\
\hline
\end{tabular}

3. Clear awareness by the Northern Border University of the use of social media in the educational process.

\begin{tabular}{|c|c|c|c|c|c|}
\hline & Yes & $\begin{array}{c}\text { To some } \\
\text { extent }\end{array}$ & No & $\mathrm{X} 2$ test on the gender element & $\begin{array}{l}\text { X2 test on the specialization } \\
\text { element }\end{array}$ \\
\hline \# & 77 & 152 & 191 & $\mathrm{P}$ Value $=0.055$ & $\mathrm{P}$ Value $=0.069$ \\
\hline$\%$ & 18.3 & 36.2 & 45.4 & $\begin{array}{l}\text { Differences in percentages are not } \\
\text { significant, meaning that the gender } \\
\text { element does not have an effect on the } \\
\text { presence of clear awareness by the } \\
\text { Northern Border University of the use of } \\
\text { social media applications in the } \\
\text { educational process }\end{array}$ & $\begin{array}{l}\text { Differences in percentages } \\
\text { are not significant Meaning } \\
\text { that the gender element does } \\
\text { not have an effect on the } \\
\text { presence of clear awareness } \\
\text { by the Northern Border } \\
\text { University of the use of } \\
\text { social media applications in } \\
\text { the educational process }\end{array}$ \\
\hline
\end{tabular}


4. The University endeavors to dissemination and spread the use of social media in the educational process.

\begin{tabular}{|c|c|c|c|c|c|}
\hline & Yes & $\begin{array}{l}\text { To some } \\
\text { extent }\end{array}$ & No & $\mathrm{X} 2$ test on the gender element & $\begin{array}{l}\text { X2 test on the specialization } \\
\text { element }\end{array}$ \\
\hline$\#$ & 63 & 195 & 162 & $\mathrm{P}$ Value $=0.029$ & $\mathrm{P}$ Value $=0.061$ \\
\hline & & & & $\begin{array}{l}\text { Differences in percentages are } \\
\text { significant, meaning that the gender } \\
\text { element has an effect on the }\end{array}$ & $\begin{array}{l}\text { Differences in percentages } \\
\text { are not significant Meaning } \\
\text { that the gender element does }\end{array}$ \\
\hline$\%$ & 15 & 46.4 & 38.6 & $\begin{array}{l}\text { University endeavor to the } \\
\text { dissemination and spread of the use of } \\
\text { social media in the educational } \\
\text { process }\end{array}$ & $\begin{array}{l}\text { not have an effect on the } \\
\text { University endeavor to the } \\
\text { dissemination and spread of } \\
\text { the use of social media in the } \\
\text { educational process }\end{array}$ \\
\hline
\end{tabular}

5. Sufficiency of the social media applications to fulfill the needs for communicating with the students and faculty members.

\begin{tabular}{llllll}
\hline Yes & $\begin{array}{l}\text { To some } \\
\text { extent }\end{array}$ & No & X2 test on the gender element & $\begin{array}{l}\text { X2 test on the specialization } \\
\text { element }\end{array}$ \\
\hline$\#$ & 119 & 203 & 98 & $\begin{array}{l}\text { P Value }=0.033 \\
\text { Differences in percentages are } \\
\text { significant, meaning that gender } \\
\text { affects the sufficiency of social } \\
\text { media to fulfill the needs for } \\
\text { communicating with the students } \\
\text { and faculty members }\end{array}$ & $\begin{array}{l}\text { P Value }=0.027 \\
\text { Differences in percentages are } \\
\text { significant Meaning that gender } \\
\text { affects the sufficiency of social } \\
\text { media to fulfill the needs for } \\
\text { communicating with the } \\
\text { students and faculty members }\end{array}$ \\
\hline
\end{tabular}

6. The use by students of social media in academic achievement.

\begin{tabular}{llllll}
\hline Yes & $\begin{array}{l}\text { To some } \\
\text { extent }\end{array}$ & No & X2 test on the gender element & $\begin{array}{l}\text { X2 test on the specialization } \\
\text { element }\end{array}$ \\
\hline$\#$ & 57 & 176 & 187 & $\begin{array}{l}\text { P Value }=0.031 \\
\text { Differences in percentages are } \\
\text { significant, meaning that the gender } \\
\text { element affects the students' use of } \\
\text { social media in the educational } \\
\text { process }\end{array}$ & $\begin{array}{l}\text { P Value }=0.047 \\
\text { Differences in percentages are } \\
\text { significant, meaning that the } \\
\text { gender element affects the } \\
\text { reasons for the students' use of } \\
\text { social media in the educational } \\
\text { process }\end{array}$ \\
\hline
\end{tabular}

7. Size of students' use of social media.

\begin{tabular}{|c|c|c|c|c|c|}
\hline & Yes & $\begin{array}{l}\text { To some } \\
\text { extent }\end{array}$ & No & $\mathrm{X} 2$ test on the gender element & $\begin{array}{l}\mathrm{X} 2 \text { test on the } \\
\text { specialization element }\end{array}$ \\
\hline$\#$ & 233 & 165 & 22 & $\mathrm{P}$ Value $=0.066$ & $\mathrm{P}$ Value $=0.034$ \\
\hline$\%$ & 55.4 & 39.3 & 5.2 & $\begin{array}{l}\text { Differences in percentages are not } \\
\text { significant, meaning that the gender } \\
\text { element does not affect the size of } \\
\text { students' use of social media }\end{array}$ & $\begin{array}{l}\text { Differences in percentages } \\
\text { are significant, meaning } \\
\text { that the gender element } \\
\text { affects the size of the } \\
\text { students' use of social } \\
\text { media }\end{array}$ \\
\hline
\end{tabular}

8. Social media contribution in achieving the educational outcomes of students.

\begin{tabular}{llllll}
\hline Yes & $\begin{array}{l}\text { To some } \\
\text { extent }\end{array}$ & No & X2 test on the gender element & $\begin{array}{l}\text { X2 test on the specialization } \\
\text { element }\end{array}$ \\
\hline$\#$ & 86 & 195 & 139 & P Value $=0.037$ & $\begin{array}{l}\text { P Value }=0.056 \\
\text { Differences in percentages } \\
\text { are not significant, meaning } \\
\text { that the gender element does } \\
\text { not affect the social media } \\
\text { contribution in achieving the } \\
\text { educational outcomes of } \\
\text { students }\end{array}$ \\
\hline
\end{tabular}


9. The presence of obstacles facing the use of social media in the academic achievement process.

\begin{tabular}{llllll}
\hline Yes & $\begin{array}{l}\text { To some } \\
\text { extent }\end{array}$ & No & X2 test on the gender element & $\begin{array}{l}\text { X2 test on the } \\
\text { specialization element }\end{array}$ \\
\hline$\#$ & 212 & 166 & 42 & P Value $=0.021$ & $\begin{array}{l}\text { P Value }=0.063 \\
\text { Differences in percentages } \\
\text { are not significant, } \\
\text { meaning that the gender } \\
\text { element does not affect the } \\
\text { presence of obstacles } \\
\text { facing the use of social } \\
\text { media in the educational } \\
\text { achievement process }\end{array}$ \\
\hline
\end{tabular}

\section{Discussion}

Through the questions that the study was keen on by introducing to the social media applications that students use and their trends in addition to the applications sought by the university and the extent of the contribution to the advancement of the educational process and the obstacles that transform the role of the spread of social media applications in improving the educational process, in addition to the actual determination of use and evaluation The points of distinction and weakness in this use to achieve the vision of the Kingdom of Saudi Arabia 2030 towards consolidating the use of information technology with a focus on the educational process, leading to the application of quality standards and academic accreditation when considering social media as one of the possibilities for increasing academic achievement and improving student performance, and accordingly, the results can be discussed in light of The following themes:

Although the Northern Border University seeks to move towards adopting social media as one of the possible academic achievement standards, studies in this subject area and about the Northern Border University are not available. This has led the researchers to consider conducting a study to evaluate the use of social media on the academic achievement process at the Northern Border University in particular. It is worth noting that the current study is compatible with the concerns and requirements to achieve the 2030 vision of the Kingdom of Saudi Arabia, which seeks to implement technology throughout the Kingdom, with a focus on education in particular. Thus, the study keeps pace with the requirements of the vision, which aims at applying the standards of quality and academic accreditation, where social media is one of the educational achievement boosters among students in addition to learning about the current reality of students' use of social media among students at the Northern Border University. The study also sets forth a proposed concept and specific recommendations that can be relied upon to activate the role of social media at the Northern Border University. This helps to improve students' performance in increasing academic achievement. Results showed that a large number of students opt for the use of social media in the educational process with a percentage exceeding $80 \%$ and that students tend to use Facebook frequently by $92 \%$, while YouTube followed by $87 \%$, then Twitter with $78 \%$. While comparing results, it became obvious that there is not enough awareness from the University of the importance of using social media in the educational process. The university gives moderate importance towards generalizing the use of social media in the educational process. Over and above that, results also demonstrated that social media is good and sufficient in the educational process and is well relied upon by students. The results also showed that social media highly contributes to the development of students' study skills and abilities, as well as increases the ability to include academic courses. Added to that, it improves the learning environment within the university. A high percentage of the student sample size uses social media to complete the educational process and increase academic achievement in the academic courses. However, the results from the point of view Students indicated that there are deficiencies in achieving direct educational results by the university in generalizing and using social media to support academic achievement. Results also showed that a large number of students do not find obstacles in using social media in the educational process and academic achievement due to the intense and widespread use of the Internet, smartphones, and tablets among students.

\section{Conclusion}

We conclude through the results that there is a varied trend among the students, where it is evident that a very high percentage of students use one or more social media applications in one 
form or the other. However, there is a clear variation between the use of social media applications, in the high use of Facebook, Twitter, and YouTube, with a moderate pattern in using the remaining social media applications. There is also a moderate trend on the part of the University in spreading the awareness of the importance of social media applications. The results show a weakness on the part of the university in generalizing the use of social media among its students, that social media applications are considered sufficient to a great extent to contribute in academic and technical communication amongst the students as well as with the faculty members, which is what prompts students to use social media, enabling them to submit and receive all educational files, communicate academically with colleagues and faculty members, form academic and personal friendships, fulfill personal needs and fill their free time. As for the size of the use of social media, the results show a varied increase in the rate of use, with the use varying between high trends in what can be called social reasons among students, with other moderate trends between the academic inclination group to increase academic achievement. Results also show that social media contribute at a higher than the average rate in the development of the educational skills and capabilities of the students as well as increasing the ability to comprehend the academic curricula, in addition to improving the learning environment within the University.

\section{Proposed Vision and Study Recommendations}

The following recommendations can be made through the study:

1. The need to work on raising awareness of spreading social media to both the students and the faculty members through the organization of workshops, training courses, and holding conferences and the positive participation by specialists with advanced studies in this respect.

2. The need to transfer the technology and establish it about the experiments in using social media at the university through international experiences and the companies active in this field.

3. The University shall endeavor more to spread awareness of the importance of social media through the distribution of tablet PCs connected to the internet to its students as well as faculty members.

4. Intensify the periodic training on the use and application of social media among the students and the faculty members.
5. The University shall commit to direct students and faculty members to prepare and exchange the academic homework, assignments, and scientific research through interfaces shared among educational groups.

\section{References}

Ahmed, S. \& Hassan, A. (2017). A Study on the Rationale of Social Media Use by the Students of King Khalid University. English Language Teaching, 10(8), 43-50. DOI. 10.5539/elt.v10n8p43.

Aksoy, M. (2018). A Qualitative Study on the Reasons for Social Media Addiction. European Journal of Educational Research, 7(4), 861-865. DOI. 10.12973/eu-jer.7.4.861.

Alghamdi, A. \& Hamed, A. (2019). Creating Scientific Dialogue through Social Media: Exploration of Saudi Pre-Service Science Teachers. Research in Science \& Technological Education, $\quad 37 \quad$ (4), 471-491. https://doi.org/10.1080/02635143.2019.1570107 Alhamadi, A. (2017). The Influence of Social Media on Saudi Graduate Students: An Explanatory Case Study of Six Saudi Graduate Students Studying in American Universities. ProQuest LLC (Ph.D. Dissertation), Kansas State University. ISSN: 978-0-3556-1377-3. https://krex.kstate.edu/dspace/handle/2097/38211

Allam, M. \& Elyas, T. (2016). Perceptions of Using Social Media as an ELT Tool among EFL Teachers in the Saudi Context. English Language Teaching, 9(7), 1-9. DOI. 10.5539/elt.v9n7p1.

Alruwaili, T. \& Ku, H. (2019). The Role of Online Communities and the Impact of Educational Social Media on Saudi Female College Students in the United States. Educational Media International, 56(2), 149-163. https://doi.org/10.1080/09523987.2019.1614244 Dudin, M., Afanasyev, V., Afanaseva, I., \& Rezakov, R. (2019). Formation of media education in Russia (from the Middle Ages to the present day). Amazonia Investiga, 8(21), 674-687. Retrieved from https://www.amazoniainvestiga.info/index.php/a mazonia/article/view/156

Freberg, K. \& Kim, C. (2018). Social Media Education: Industry Leader Recommendations for Curriculum and Faculty Competencies. Journalism and Mass Communication Educator, 73(4), p. 379-391. https://doi.org/10.1177/1077695817725414.

Hassell, M. \& Sukalich, M. (2016). A Deeper Look into the Complex Relationship between Social Media Use and Academic Outcomes and Attitudes. Information Research: An International Electronic Journal, 21(4). 


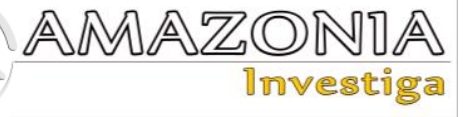

https://epublications.marquette.edu/mgmt_fac/2 $72 /$

Hosseini, F., Maktabi, G., Yailagh, M., \& Yakhchali, A. (2019). The effects of teaching reflective thinking model on academic selfefficacy, achievement motivation, intention certainty, and reflective thinking of the of Farhangyan University students in Ahvaz. Ahvaz, Iran. Amazonia Investiga, 7(13), 401418. Retrieved from https://www.amazoniainvestiga.info/index.php/a mazonia/article/view/581

Kalpidou, M., Costin, D. \& Morris, J. (2011). The relationship between Facebook and the wellbeing of undergraduate college students. Cyberpsychology, Behavior, and Social Networking, 14(4), 183-9. DOI. 10.1089/cyber.2010.0061.

Kumar, V. \& Nanda, P. (2019). Social Media in Higher Education: A Framework for Continuous Engagement. International Journal of Information and Communication Technology Education, 15(1), Article 8, 109-120. DOI. 10.4018/IJICTE.2019010108.

Le, T., Dobele, A. \& Robinson, L. (2019). Information Sought by Prospective Students from Social Media Electronic Word-of-Mouth during the University Choice Process. Journal of Higher Education Policy and Management, 41(1), 18-34. https://doi.org/10.1080/1360080X.2018.153859 5.

Lee, G., Lee, J. \& Kwon, S (2011). Use of Social-Networking Sites and Subjective WellBeing: A Study in South Korea. Cyberpsychology, Behavior, and Social Networking, 14(3), 151-5. DOI. 10.1089/cyber.2009.0382.

Lei, P. \& Wu, Q. (2007). Introduction to Structural Equation Modeling: Issues and Practical Considerations. Educational Measurement: Issues and Practice, 26(3), 33-43. Lundgren, L. \& Crippen, K. (2019). Learning and the Practice of Social Media in Informal Science Education Centers. International Journal on E-Learning, 18(1), 31-52. https://eric.ed.gov/?id=EJ1204215

Melchiorre, M. \& Johnson, S. (2017). Finding New Ways to Reach Older Students: Creating a Social Media Marketing Plan for Professional and Continuing Higher Education Programs. Journal of Continuing Higher Education, 65(2), 73-81.

https://doi.org/10.1080/07377363.2017.1320178 Naseem, M., Arshad-A. \& Doyle, S. (2019). Social Media as Space for Peace Education: Conceptual Contours and Evidence from the Muslim World. Research in Comparative and
International Education, 12(1), 95-109. https://doi.org/10.1177/1745499917696422.

Neto, R., Golz, N. \& Polega, M. (2015). Social Media Use, Loneliness, and Academic Achievement: A Correlational Study with Urban High School Students. Journal of Research in Education, 25(2), 28-37. https://eric.ed.gov/?id=EJ1097983

O'Neill, B. (2019). Ten Tools for Creating Attention-Getting Social Media Messages. Journal of Extension, 57(2), Article 2TOT7. https://tigerprints.clemson.edu/cgi/viewcontent. cgi? article $=1439 \&$ context $=$ joe

Razmjooei, P., Gharbi Jahromi, M., Managheb, S., Hosseini, M., \& Shahamat, N. (2019). The role of information and communication technology in the process of teaching-learning and analyzing its application in primary schools of Qavar. Amazonia Investiga, 7(13), 82-89. Retrieved from https://www.amazoniainvestiga.info/index.php/a mazonia/article/view/497

Rouis, S., Limayem, M. \& Salehi-Sangari, E. (2011). Impact of Facebook Usage on Students' Academic Achievement: Role of Self-Regulation and Trust. Electronic Journal of Research in Educational Psychology, (9) 961-994. DOI. 10.25115/ejrep.v9i25.1465.

Sanderson, J. (2018). Thinking Twice Before You Post: Issues Student-Athletes Face on Social Media. New Directions for Student Services, 163, 81-92. DOI. 10.1002/ss.20272.

Santoveña-Casal, S. (2019). The Impact of Social Media Participation on Academic Performance in Undergraduate and Postgraduate Students. International Review of Research in Open and Distributed Learning, 20(1), 125-143. DOI. https://doi.org/10.19173/irrodl.v20i1.3751. Sapkota, K. \& Vander, J. (2018). Social Media Acceptance and Usage by Business Communication Faculty. Business and Professional Communication Quarterly, 81(3), 328-350.

https://doi.org/10.1177/2329490618777818.

Sharma, V. (2019). Saudi Students' Perspective on Social Media Usage to Promote EFL Learning. Online Submission, International Journal of Linguistics, Literature, and Translation, 2(1), 129-139. Retrieved from https://www.semanticscholar.org/paper/SaudiStudents'-Perspective-on-Social-Media-UsageSharma/0042f9f3f1ed24a35744b4e6c128fe1d95 $9 \mathrm{ddc} 5 \mathrm{~b}$

Shields, A. \& Peruta, A. (2019). Social Media and the University Decision. Do Prospective Students Care? Journal of Marketing for Higher Education, 29(1), 67-83. https://doi.org/10.1080/08841241.2018.1557778 
Sidorov, V. (2019). Value-Based Indifference of Media Technologies. Amazonia Investiga, 8(21), 568-575. Retrieved from https://www.amazoniainvestiga.info/index.php/a mazonia/article/view/137

Watson, A. (2017). Manage Your Social Media in 5 Minutes a Day. Public Services Quarterly, 13(1), 41-47. https://doi.org/10.1080/15228959.2016.1268942 West, S. (2017). Confronting Negative Narratives: The Challenges of Teaching Professional Social Media Use. Business and Professional Communication Quarterly, 80(4), 409-425.

https://doi.org/10.1177/2329490617723118.

Woods, K., Gomez, M. \& Arnold, M. (2019). Using Social Media as a Tool for Learning in
Higher Education. International Journal of WebBased Learning and Teaching Technologies, 14(3), Article 1, 1-14. DOI. 10.4018/IJWLTT.2019070101.

Yildiz, E., Çengel, M. \& Alkan, A. (2019). Social Media Attitudes among Vocational School Students. International Journal of Evaluation and Research in Education, 8(3), 384-391. DOI. http://doi.org/10.11591/ijere.v8i3.20248.

Zoabi, K. (2012). Self-Esteem and Motivation for Learning among Minority Students: A Comparison between Students of Pre-Academic and Regular Programs. Creative Education, 03(08), 1397-1403. DOI. 10.4236/ce.2012.38204. 